\title{
Effect of moringa leaves and ginger rhizomes on the microbial quality of Oreochromis niloticus processed with three different kilns
}

\begin{abstract}
This study examined the bacteriological quality of smoked fish (Oreochromis niloticus) smoked with IKDK, IAK and Solar Dryer preserved with Moringa leaves and Ginger rhizone. Samples of fish were procured from Bagudu Farms ltd Jalingo. Seventy five pieces of Oreochromis niloticus were used for the experiment. Four of the smoked fish samples were evaluated using standard analytical techniques. The bacteriological quality of the fishes ranged from $8.69 \times 10^{5}$ for Whole Moringa and the highest figure of $9.66 \times 10^{5}$ for Whole control. In the Adrian Kiln, the Oreochromis niloticus, Fillet Ginger had $6.30 \times 10^{5}$ while Whole Moringa recorded $8.32 \times 10^{5}$ respectively. The total bacterial count in the Solar Box Dryer (SBD) indicated $5.77 \times 10^{5}$ for Whole Moringa and $8.10 \times 10^{5}$ for Whole Ginger. The total fungi count had $9.10 \times 10^{5}$ and $7.10 \times 10^{5}$ for whole control and Fillet Moringa respectively. In the case of the Adrian kiln, the fishes had $9.10 \times 10^{5}$ Moringa and $7.22 \times 10^{5}$ for Whole control. In the SBD the figures are lower with $5.99 \times 10^{5}$ and $8.96 \times 10^{5}$ for Fillet Ginger and Whole Moringa respectively. The Total Coliform Count in IKDK had $5.99 \times 10^{5}$ for Fillet moringa and $8.65 \times 10^{5}$ for whole control. In the Adrian Kiln, the Total Coliform Count had whole Moringa with $7.63 \times 10^{5}$ and least values in Fillet Ginger with $5.66 \times 10^{5}$. In the Solar Box Dryer, the Total Coliform Count identified recorded $4.66 \times 10^{5}$ in Fillet Ginger and $8.25 \times 10^{5}$ in Whole Moringa.
\end{abstract}

\section{Introduction}

Fish is one of the best sources of proteins, vitamins and minerals and are essential nutrients required for supplementing both infant and adult diets. ${ }^{1}$ According to Adekoya and Miller, ${ }^{2}$ fish and fish products constitute more than $60 \%$ of the total protein intake in adults especially in rural areas. According to $\mathrm{FAO},{ }^{3}$ to maintain the present per capita fish consumption level of $13 \mathrm{~kg}$ per year, 2.0 million metric tons of fish food would be required. It has been noted by some researchers that the only means of meeting up with this annual fish demand for the country would be through a pragmatic option of intensive fish farming. ${ }^{4}$

In Nigeria, fish is eaten fresh and smoked and form a much cherished delicacy that cut across socio-economic, age, religions and educational barriers. ${ }^{5}$ Shewan, ${ }^{6}$ reported that, the microbial flora associated with freshly harvested fish is principally a function of the environment in which the fish are caught and not of the fish species; hence, the indigenous microbial populations of fish can vary significantly. A similar report on fish confirmed that, fish because of their soft tissues and aquatic environment are extremely susceptible to microbial contamination. Abolagba and Uwagbai, ${ }^{7}$ reported that Millions of bacteria, many of them potential spoilers, are present in the surface slime, on the gills and in the intestines of live fish. More so, bacterial growth and invasion on the fish are prevented by the body's natural defense system during life but after death the defense system breaks down and the bacteria multiply and invade the flesh. Poor postharvest technology (handling, preservation and processing) have been reported earlier to have the ability to cause unhealthy situation resulting in massive spoilage.

Akande ${ }^{8}$ reported that an estimate of $40 \%$ postharvest losses of total fish landings have been reported in Nigeria. Saliu, ${ }^{9}$ also reported that fish spoilage in Nigeria is influenced to a large extent by high ambient temperatures, considerable distances of landing ports to points of utilization and poor as well as inadequate infrastructure for post - harvest. Olayemi et al., ${ }^{10}$ reported that several methods have
Volume 8 Issue 2 - 2019

\author{
Gawi GO,' Fili KB, ${ }^{2}$ Sogbesan $O A^{3}$ \\ 'Department of Fisheries, Taraba State College of Agriculture \\ Jalingo, Nigeria \\ ${ }^{2}$ Department Food Science Technology Mautech, Nigeria \\ ${ }^{3}$ Department of Fisheries Mautech, Nigeria
}

\section{Correspondence: Gawi GO, Department of Fisheries, Taraba State College of Agriculture Jalingo, Nigeria,} Email g.gawi@yahoo.com

Received: March 01, 2019 | Published: March 28, 2019 been adopted to preserve fish both for long and short time usage, among the several methods of long term preservation of fish, smoking has been reported as perhaps the simplest method which does not require sophisticated equipment or highly skilled workers. Fish provides $40 \%$ of the dietary intake of animal protein to the average Nigerian FDF. ${ }^{11}$ Traditionally, report has shown that fish is smoked in pits or on raised smoking "tables" where the control of heat is difficult and at times impossible, ${ }^{12}$ Also, the smoked fish would often be exposed to dust and heavy microbial contamination during the process of traditional smoking which gives the final products high microbial load even immediately after smoking, this agrees with the findings of Abolagba and Iyeru, ${ }^{13}$ who reported that lack of proper smoking and proper hygienic handling of smoked fish products would result in a very high microbial load and open flame smoking of fish has been noted to produce cancer promoting compounds in the body. In an attempt to reduce the problems often encountered during smoking, Nigeria Stored Products Research Institute (NSPRI) fish smoking kiln was developed. Due to handling and the exposure to the environment during and after smoking, smoked fish often comes out with heavy microbial load after smoking therefore (Table 1-7).

Micro-organisms such as bacteria, mould and yeast are responsible for putrid action and the development of unsightly appearance and toxic substances in the fish which may be passed to consumers. Microorganisms are often arrested by controlling product water and or salt content, chemical treatments, temperature reduction and by good sanitation and good handling practices. ${ }^{15}$ Microbial spoilage is a major concern for so called perishable food such as meats, poultry, fish bakery products, milk, and juice; which could also lead to food borne disease. Potential food spoilage microorganisms include bacteria, fungi (mold and yeast), viruses, and parasites. Some microorganisms simply cause spoilage of foods while others can cause illness or even death if it is consumed. ${ }^{15}$ Prior to harvest, fish are protected by a skin that secretes antimicrobial compounds, such as lysozyme and antibodies in the blood. This self protection and regulating feature is indicative of the 
biochemical compositions of fish. However, harvesting results in death of fish with the following consequences as observed by (International Commission on Microbiological Specifications for Foods - ICMSF, 2005). ${ }^{16}$ Antimicrobials are no longer produced or distributed and microflora penetrates the skin from the outside surface and intestines and gills. So, the development of these spoilage conditions in fish and fishery products is due to a combination of chemical, autolytic and microbial changes, but the spoilage rate can be reduced by different processing and preservation techniques. ${ }^{17}$

Table I Total Bacteria Count in Improved Kainji Drum Kiln smoked Oreochromis niloticus after bio preservation

\begin{tabular}{lll}
\hline Samples & M. organisms isolated & $\begin{array}{l}\mathbf{C C} \times 10^{5} \mathrm{cfu} / \\
\mathbf{m L}\end{array}$ \\
\hline Whole Control & Lactobacillus, S. aureus, B. cerus, E. coli & $9.66 \times 10^{5}$ \\
Fillet Control & E. coli, Klebsella, Strep., Shigella & $8.76 \times 10^{5}$ \\
Whole Ginger & Klebsella spp., Yeast cells, E. coli, S. typhii & $9.44 \times 10^{5}$ \\
Fillet Ginger & Staph., S. typhii, Klebsella, E.coli, Shigella & $9.23 \times 10^{5}$ \\
Whole Moringa & Lactobacillus, E. coli, S. aureus, B. subtilis & $8.69 \times 10^{5}$ \\
Fillet Moringa & S. aureus, E. coli, B. subtilis, Strep. & $8.79 \times 10^{5}$
\end{tabular}

M. organisms, Microorganisms isolated; CC, Colony count

Table 2 Total Bacterial Count Oreochromis niloticus (Adrian) after preservation

\begin{tabular}{lll}
\hline Samples & M. organisms isolated & CC $\times 10^{5} \mathrm{cfu} / \mathrm{mL}$ \\
\hline Whole Control & Klebsella, E. coli, S. aureus & $7.66 \times 10^{5}$ \\
Fillet Control & Lactobacillus, S. typhii, E. coli & $7.32 \times 10^{5}$ \\
Whole Ginger & Shigella spp., S. aureus, S. typhii & $7.86 \times 10^{5}$ \\
Fillet Ginger & S. aureus, B. cereus, Strep. Spp. & $6.30 \times 10^{5}$ \\
Whole Moringa & Streptocuccus spp., E. coli, Klebsella, & $8.32 \times 10^{5}$ \\
Fillet Moringa & S. aureus & $6.90 \times 10^{5}$ \\
\hline
\end{tabular}

M. organisms, Microorganisms isolated; CC, Colony count

Table 3 Total Bacteria Count Oreochromis niloticus (Solar) after preservation

\begin{tabular}{lll}
\hline Samples & M. organisms isolated & CC $\times 10^{5} \mathrm{cfu} / \mathrm{mL}$ \\
\hline Whole Control & Shigella spp., E. coli, Staph. & $7.66 \times 10^{5}$ \\
Fillet Control & E. coli, B. cereus & $6.11 \times 10^{5}$ \\
Whole Ginger & E. coli, Klebsella spp., B. subtilis & $8.10 \times 10^{5}$ \\
Fillet Ginger & Lactobacillus, B. subtilis & $7.80 \times 10^{5}$ \\
Whole Moringa & S. aureus, & $5.77 \times 10^{5}$ \\
Fillet Moringa & Yeast cells, Candida, E. coli & $8.99 \times 10^{5}$
\end{tabular}

M. organisms, Microorganisms isolated; CC, Colony count

Table 4 Fungi Identified from Oreochromis niloticus (Drum) after preservation

\begin{tabular}{lll}
\hline Samples & M. organisms isolated & CC $\times 10^{5} \mathrm{cfu} / \mathrm{mL}$ \\
\hline Whole Control & A. fumigates, Candida sp & $9.10 \times 10^{5}$ \\
Fillet Control & A. vulgaris, Parasitilum & $7.2 \times 10^{5}$ \\
Whole Ginger & B. ceusus, Pen. Spp. & $7.36 \times 10^{5}$ \\
Fillet Ginger & B. Caesus, A. nigar & $7.55 \times 10^{5}$ \\
Whole Moringa & A. fumigates, Cadida albica & $7.79 \times 10^{5}$ \\
Fillet Moringa & A. niger P. vulgaris & $7.10 \times 10^{5}$
\end{tabular}

M. organisms, Microorganisms isolated; CC, Colony count
Table 5 Fungi identified from Oreochromis niloticus (Adrian) after preservation

\begin{tabular}{lll}
\hline Samples & M. organisms isolated & $\begin{array}{c}\text { CC } \times 10^{5} \\
\mathbf{c f u} / \mathrm{mL}\end{array}$ \\
\hline Whole Control & A. niger, A. flavus, Candida & $7.33 \times 10^{5}$ \\
Fillet Control & P. vulgaris, A. flavos, Trycophyton, A. niger & $8.22 \times 10^{5}$ \\
Whole Ginger & A. flavus, A. niger, Trycophyton, Candida & $8.12 \times 10^{5}$ \\
Fillet Ginger & A. flavus, A. niger, Candida & $7.38 \times 10^{5}$ \\
Whole Moringa & A. fumigates, A. flavus, A. niger Cadinda spp & $9.10 \times 10^{5}$ \\
Fillet Moringa & Rhisopus, Fusarium, spp., Candida, A. flavus & $8.21 \times 10^{5}$ \\
\hline M. organisms, Microorganisms isolated; CC, Colony count \\
Table 6 Fungi indentified from Oreochromis niloticus (Solar) after preservation \\
\hline Samples & \multicolumn{1}{c}{ M. organisms isolated } & $\mathbf{C C} \times 10^{5} \mathrm{cfu} / \mathrm{mL}$ \\
\hline Whole Control & P. vulgaris, Rhizophus & $6.22 \times 10^{5}$ \\
Fillet Control & A. fumigates P. vulgaris, A. niger & $7.55 \times 10^{5}$ \\
Whole Ginger & B. cereus, P. vulgaris, A. flavus & $7.01 \times 10^{5}$ \\
Fillet Ginger & Candida, A. parasiticum & $5.99 \times 10^{5}$ \\
Whole Moringa & A. nigar, P. vulgaris, & $8.96 \times 10^{5}$ \\
Fillet Moringa & Yeast cells, Candida spp., A. niger & $7.35 \times 10^{5}$
\end{tabular}

M. organisms, Microorganisms isolated; CC, Colony count

Table 7 Total Coliform Count Indentified the treated samples (cfu/ml). (Oreochromis niloticus) after preservation (Drum)

\begin{tabular}{ll}
\hline Samples & Coliform isolated $\left(\mathrm{cfu} / \mathrm{mL} \times 10^{5}\right)$ \\
\hline Drum kiln & \\
Whole Control & $8.65 \times 10^{5}$ \\
Fillet Control & $7.22 \times 10^{5}$ \\
Whole Ginger & $7.50 \times 10^{5}$ \\
Fillet Ginger & $7.66 \times 10^{5}$ \\
Whole Moringa & $6.15 \times 10^{5}$ \\
Fillet Moringa & $5.99 \times 10^{5}$ \\
Adrian Kiln & \\
Whole Control & $6.83 \times 10^{5}$ \\
Fillet Control & $6.89 \times 10^{5}$ \\
Whole Ginger & $6.60 \times 10^{5}$ \\
Fillet Ginger & $5.66 \times 10^{5}$ \\
Whole Moringa & $7.63 \times 10^{5}$ \\
Fillet Moringa & $5.77 \times 10^{5}$ \\
Solar Dryer & \\
Whole Control & $6.30 \times 10^{5}$ \\
Fillet Control & $7.66 \times 10^{5}$ \\
Whole Ginger & $6.75 \times 10^{5}$ \\
Fillet Ginger & $4.66 \times 10^{5}$ \\
Whole Moringa & $8.25 \times 10^{5}$ \\
Fillet Moringa & $6.99 \times 10$ \\
\hline & \\
& \\
\hline
\end{tabular}




\section{Materials and methods}

\section{Study area}

The study was conducted in Jalingo, Taraba State, Nigeria. Jalingo is situated between longitude $8^{0} 89^{\prime} \mathrm{N}$ and Latitude $11^{\circ} 36 \mathrm{E}$ with on a land mass of it climatic condition tallies with the two (dry and wet) season commonly experienced in the tropical region. The wet season covers up to seven months starting from April to October with average annual rainfall range of $1058 \mathrm{~mm}-1300 \mathrm{~mm}$ while the dry season covers about five months starting from November to March. Predominantly, farming and livestock rearing are the major occupation of the people within the study area. ${ }^{18}$

\section{Experimental design}

The experiment was carried out at in the College of Agriculture Jalingo. Jalingo lies on the latitude $8^{0} 5^{\prime \prime}$ North and longitude $11^{0} 25^{\prime}$ East. ${ }^{18}$ The research was conducted with a Complete Randomised Design (CRD) with three Factors, each at two or three levels

\section{Collection and processing of Clarias gariepinus and} Oreochromis niloticus

Seventy-five Oreochromis niloticus species samples each was purchased from Bagudu farms Ltd. Jalingo. The fish sample collected was washed in clean water, eviscerated and dipped in a brine solution ( $5 \%$ sodium chloride) for 10 minutes and allow to drain as suggested by Ikeme and Bhandary. ${ }^{19}$ The weight of the fish was taken as the average mean was $75.73 \mathrm{~g}$. The fish species was treated whole and fillets.

\section{Fish processing and smoking procedures}

\section{Processing using kainji improved drum kiln}

Whole and gutted fish was spread on the racks with the open end facing the fire source to allow for quick dehydration of the fish. The drum is then covered on top and the side door, the temperature of the chamber was $80^{\circ} \mathrm{C}$. The drying rate or moisture loss was measured by weighing the fish at an interval of 30 minutes until constant weight is obtained. The moisture content was evaluated on a dry weight or wet weight basis. The procedure was repeated for another portion and the results averaged. Frequent checking of the fish was done to take precaution against charring of the product and get uniform heat, until the fish is completely smoked and dried. The fish was allowed to cool at ambient temperature before it was packaged in aluminum foil for preservation

\section{Processing with the adrian kiln}

The fish in the Adrian Smoking Kiln is hung vertically on metal rods inside the chamber. The fish hanged vertically allows them to drip any fluids or fats, thus facilitating much more rapid drying. The top rods are secured to the roof and the lower ones hung from each other with simple hooks. This is a very efficient system allowing unimpeded air flow

\section{Processing with metal box solar dryer}

The fish was spread inside the box and drying was achieved by heat radiation from the sun through the polyurethane glass into the box that is painted black to absorb and retain heat. The fish was turned hourly to allow uniform drying.

\section{Drying efficiency of the kiln (\%)}

The drying efficiency was determined using the differences in moisture loss and the time taken to dry.

\section{Microbiological analysis}

The samples were homogenized before the microbial analysis commenced. Homogenization was done in the stomacher at high speed by adding 25 grams of sample and $225 \mathrm{ml}$ sterile pepton water. After the preparation of this 10-1 serial dilution the next step was to prepare ten-fold serial dilutions by transferring $1 \mathrm{~mL}$ of the initial inoculums into $9 \mathrm{~mL}$ of sterile 30 pepton water with the help of sterile pipette. The procedure was repeated for many serial dilution as required $\left(10^{-2}, 10\right.$ ${ }^{3}, 10^{-4}$ etc). Then the following procedures were used for the specific microbes:

Aerobic plate count (APC) about $0.1 \mathrm{~mL}$ of each required serial dilution was aseptically spread and plated on plate count agar using L-shaped glass rods into a labeled Petri-dish in duplicate. The Petri dish was inverted and inoculated in an incubator at $35^{\circ} \mathrm{c}$ for $24 \mathrm{hrs}$. Finally count the colonies by colony counter.

Yeast and mould similarly $0.1 \mathrm{~mL}$ of each required dilution was aseptically spread and plated on potato dextrose agar using L-shaped glass rods into a labeled Petri-dish in duplicate. The Petri dish was inverted and inoculated in an incubator at $35^{\circ} \mathrm{c}$ for $48-72 \mathrm{hrs}$. Finally count the colonies by colony counter.

Enterobacteriaceae about $0.1 \mathrm{~mL}$ of the initial inoculums and each required dilution was aseptically spread and plated on violet red bile glucose (VRBG) agar using L-shaped glass rods into a labeled petridish in duplicate. Then the petri dish was inverted and placed in anaerobic jar. Finally place the loaded anaerobic jar in incubator at $37^{\circ} \pm 1^{\circ} \mathrm{C}$ for $24-48 \mathrm{hrs}$. At last count all red colonies producing gas regardless of acid production. Also count all non-gassing colonies with yellow acid zones. After counting each colony the following mathematical relation was used to calculate total colony forming unit per gram of sample:

\section{Results}

\section{Total bacteria count identified from preserved Oreochromis niloticus}

The values in IKDK recorded $8.69 \times 10^{5}$ for Whole Moringa and the highest figure of $9.66 \times 10^{5}$ for Whole control. Fillet Ginger had $6.30 \times 10^{5}$ while Whole Moringa recorded $8.32 \times 10^{5}$ respectively. The total bacterial count in the Solar Box Dryer (SBD) indicated 5.77 $\times 10^{5}$ for Whole Moringa and $8.10 \times 10^{5}$ for Whole Ginger.

\section{Total fungi count by different processors from preserved Oreochromis niloticus}

The total fungi count had $9.10 \times 10^{5}$ and $7.10 \times 10^{5}$ for whole control and Fillet Moringa respectively. In the case of the Adrian kiln, Oreochromis niloticus had $9.10 \times 10^{5}$ Moringa and $7.22 \times 10^{5}$ for Whole control. In the SBD also, the figures are lower with $5.99 \times 10^{5}$ and $8.96 \times 10^{5}$ for Fillet Ginger and Whole Moringa respectively.

\section{Total coliform count by different processors from preserved Oreochromis niloticus}

The Total Coliform Count in IKDK also had $5.99 \times 10^{5}$ for Fillet moringa and $8.65 \times 10^{5}$ for whole control. In the Adrian Kiln, the Total Coliform Count revealed that Moringa with $7.63 \times 10^{5}$ and least values in Fillet Ginger with $5.66 \times 10^{5}$. In the Solar Box Dryer, the Total Coliform Count identified range between $4.66 \times 10^{5}$ in Fillet Ginger and $8.25 \times 10^{5}$ in Whole Moringa. 


\section{Discussion}

Fish samples from all processors yielded both fungi and bacteria. The pattern of variation of microbes identified and counts were presented. From the total samples of smoked and dried fish examined, all showed positive results for bacterial and fungal isolates. These results agreed with the report of Brown ${ }^{24}$ that bacteria and fungi are contaminates of smoked fish.

Sixteen different types of bacteria and eleven different types of fungi were isolated and these include; Bacillus cereus, Staphylococus aureus, Escherichia coli, Streptococus, Klebsiella spp. (Bacteria) while Fungi are; A. niger, P. vulgaris, A. parasiticum. These organisms may have contaminated the smoked and dried fish through handling, air and soil. It may also be due to increase in moisture content especially during storage and increase in temperature which favours the growth of these organisms.

The microbial count of the processed smoked and dried fish samples in different kilns and the Solar dryer. The study indicated that the bacteria count in the Drum kiln was highest compared to the Adrian and Solar dryer. The higher Microbial counts on the Drum kiln compared to the Adrian and Solar drier may be likely due to lack of proper smoking and/or improper hygiene and handling procedures. This is in agreement with the finding of Abolagba and Iyeru ${ }^{13}$ who reported that lack of proper smoking and hygienic handling of smoked fish products will result in very high microbial load. This was also corroborated by Eyo $^{21}$ who stated that smoked fish samples may have a relatively high water activity level which is a prerequisite for microbial growth.

Aurognosa Spp. and S. typhii had the highest frequency of occurrence with the values of $100 \%$ and $95 \%$. Klebsiella spp. and Pseudomonas Spp. Both had 50\% occurrence in each of the fish species While $E$. coli $70 \%$ respectively.

The drum kiln also demonstrated a higher colony count of up to $9.99 \times 10^{5} \mathrm{cfu} / \mathrm{ml} 9.66 \times 10^{5}$ than the Adrian kiln and Solar dryer with $5.77 \times 10^{5}$ respectively. In the case of the preserved fish samples, Streptococcus was highest with $100 \%$ occurrence. E. coli had 55\% occurrence Klebsiella Spp. had 40\% occurrences respectively. S. typhii and B. subtilis had $50 \%$.

A high population of bacteria in food indicates the general quality of the food and the degree of spoilage it might have undergone..$^{22}$ Yagoub reported that although only a few infectious agents in fish are able to infect humans, some exceptions such as Salmonella exist that may result in fatalities. However, the greatest risk to human health is due to the consumption of raw or insufficiently cooked fish and fish products.

Three main natural factors have been implicated in fish deterioration which includes: activities of micro-organism, chemical deterioration, such as the breakdown of fats and enzymatic activities and insect infestation. Micro-organisms such as bacteria, mould and yeast are responsible for putrid action and the development of unsightly appearance and toxic substances in the fish which may be passed to consumers. Micro-organisms are often arrested by controlling product water and or salt content, chemical treatments, temperature reduction and by good sanitation and good handling practices. ${ }^{14}$

Adelaja et al., ${ }^{14}$ also observed that chemical deterioration include the oxidation of fat that causes rancid flavor, breakdown of the edible flesh by enzymes (autolysis) with the production of off-flavor and odour and other chemical reactions like rancidity and lipid oxidation. Insect infestation such as blowflies and beetles attack fish at various stages of handling, processing and storage causing losses of the edible flesh. Blowflies may oviposit on fresh fish that have been exposed and produce maggots which pupate and the emerging adults may re-infect another batch of drying fish. Beetles may invade dried fish during storage and feed extensively on fish flesh. ${ }^{23}$ Insect feeding activity may cause up to $50 \%$ loss in weight of dried fish in storage.

Several factors contribute to such spoilage in fish, including interactions between the products and handling equipment, interactions between the product and the surrounding environment, and the inherent self destruction biochemical changes that take place inside the fish once it is harvested. The occurrence of spoilage in fish is manifested and perceived by the end user through changes in several sensory perceptions, including odor, color, shape, taste, and texture and probably the chemical composition. ${ }^{24}$

Microbial spoilage is a major concern for so called perishable food such as meats, poultry, fish bakery products, milk, and juice; which could also lead to food borne disease. Potential food spoilage microorganisms include bacteria, fungi (mold and yeast), viruses, and parasites. Some microorganisms simply cause spoilage of foods while others can cause illness or even death if it is consumed. ${ }^{15}$ Prior to harvest, fish are protected by a skin that secretes antimicrobial compounds, such as lysozyme and antibodies in the blood. This self protection and regulating feature is indicative of the biochemical compositions of fish. However, harvesting results in death of fish with the following consequences as observed by (International Commission on Microbiological Specifications for Foods - ICMSF, 2005).

Cessation of energy supply for normal body function, cell membranes are no longer energized, and melecules and ions can freely diffuse, antimicrobials are no longer produced or distributed and microflora penetrates the skin from the outside surface and intestines and gills. So, the development of these spoilage conditions in fish and fishery products is due to a combination of chemical, autolytic and microbial changes, but the spoilage rate can be reduced by different processing and preservation techniques. ${ }^{17}$

\section{Acknowledgments}

None.

\section{Conflicts of interest}

The author does not declare any conflict of interest.

\section{References}

1. Abdullahi SA, Investigation on nutritional status of Chrysicthys nigrodigitatus, Barus filamentous and Aucheoglanis occidentalis (Family: Bagridae). Journal of Arid Zone Fisheries. 2001;1:39-50.

2. Adekoya BB, JW Miller, Fish cage culture potential in Nigeria: $A n$ overview of national cultures. Agric. Focus.2004;1:10-16.

3. FAO. Year Book of Fishery Statistics Summary Table. 2006.

4. Ezeri GNO, Olaoye OJ, Agbon AO. Fish Fingerlings Production and Management. Agricultural Media Res ources and Extension Centre, University of Agriculture, Abeokuta. 2009; 36 p.

5. Adebayo-Tayo BC, Onilude AA, UG Patrick UG. Mycoflora of Smokedried Fishes Sold in Uyo, Eastern Nigeria. World Journal of Agricultural Science. 2008;4(3):346-350. 
6. Shewan JM. The Microbiology of Sea Water Fish. In Fish as Food Editted by G Borgstrom, New York Academic press. 1961; p 487.

7. Abolagba OJ, Uwagbai EC. A Comparative Analysis of the Microbial Load of Smoke-Dried Fishes (Ethmalosa Fimbriata and Pseudotolithus Elongatus) Sold in Oba and Koko Markets in Edo and Delta States, Nigeria at Different Seasons. Australian Journal of Basic and Applied Sciences. 2011;5(5):544-550.

8. Akande GR. Post-harvest processing in Fisheries. A paper presented at training for officers of UNDP assisted Program me on artisanal fisheries development, Ogun State at Federal College of Fisheries and Marine Technology, Lagos. 1996; p.1-20.

9. Saliu JK. Effect of smoking and frozen storage on the nutrient composition of some African fish. Advance Natural Applied Science.2008;2(1):16-20.

10. Olayemi FF, Adedayo MR, Bamishaiye EI, et al. Proximate composition of catfish (Clarias gariepinus) smoked in Nigerian stored products research institute (NSPRI): Developed kiln. International Journal of Fisheries and Aquaculture. 2011;3(5):96-98.

11. Federal Department of Fisheries. Fishery Statistics. Federal Department of Fisheries, Abuja, Nigeria. 1997.

12. Afolabi OA. Quality changes in Nigeria Traditionally Processed Freshwater species. Journal Food Technology. 1984;18:17-29.

13. Abolagba OJ, Iyeru OA. Study of insects' pests infecting Traditionally Processed Fish sold in Benin city metropolis, Nigeria. Nigerian Journal of Applied Science. 1998;16:25-29.

14. Adelaja OA, Olaoye OJ, Ikenwelwe SS, et al. Composition of microbial load association with smoked fish (chryschthys nigrodigitatus) in Ogun water side in Ogun State Nigeria, Global Journal of Science Frontier Resources. Agriculture and veterinary, 2013;13(8):34-39.

15. Singh TK, Cadwallader KR. Ways of measuring shelf-life and spoilage. In: Understanding and measuring the shelf-life of food, Steele R. ed USA, CRC press. 2004; p.165-179.
16. International Commission on Microbiological Specifications For Foods (ICMSF). Fish and fish products (Microorganisms in Fish Products). In: Microorganisms in foods 6. Microbial Ecology of food commodities: Kluwer Academic/Plenum Publishes. New York, USA, 2005; p.172-249.

17. Ellis FD. Meat Smoking Technology. In: Meat science and applications, Hu YH, Nip WK, Rogers RW. eds. Marcel Dekker, New York; 2001.

18. Oruonye ED. The challenges of Fishery Resources Management Practice in Mayo - Ranewo Community in Ardo- Kola Local Government Area, Taraba State Nigeria. Global Journal of Science Frontier Research.2014;14(3):5-15.

19. Ikeme AI, CS Bhandary. Effect of Spice Treatment on the Quality of hotsmoked Mackerel (Scomber scombrus). Presented at the $7^{\text {th }}$ FAO Expert consultation in Africa, Senegal. 2001; 10 p.

20. Brown GE. Isolation and Identification of Bacteria in retailed smoked fish within Bauchi metropolis. Journal of Pharmacy and Biological Sciences. 2004;3:1-5.

21. Eyo AA. Fish Processing Technology in the tropics. University of Ilorin press, Nigeria. 2001; p.37-103.

22. Yagoub SO, Ahmed TM, Pathogenic Microorganisms in Freshwater samples collected from Khartum central market. Sudan Journal of Veterinary Science and Animal Husbandry.2004;43(1-2):32-37.

23. Sogbesan OA, Onwukike C, Onyia LU, et al. Comparative Studies on the efficiency of some economically feasible Fish Processors in North-East Nigeria. National Monthly Refered. Journal of Research in Science and Technology. 2012;1:6.

24. Opara UL, Al-Jufaili MS, Rahman MS. Post harvest Handling and Preservation of Fresh Fish and Seafood. In: Handbook of Food Preservation. Rahman MS ed. USA, CRC press, 2007; p.151-173. 